\title{
Motivation and Organizational Citizenship Behaviour of Academics in Universities in Akwa Ibom State, Nigeria
}

\author{
${ }^{1}$ Eno Etudor-Eyo, PhD \& ${ }^{2}$ Ime Willie Atakpa
}

Department of Curriculum Studies, Educational Management and Planning Faculty of Education, University of Uyo, Uyo, Akwa Ibom State, Nigeria

\begin{abstract}
The paper examined the extent to which motivation predicts organisational citizenship behaviour of academics in universities in Akwa Ibom State, Nigeria. Three research questions were raised to guide the study while three null hypotheses were tested at .05 alpha level of significance. Ex-post facto design was adopted for the study. Population of the study comprised all the 1856 academics in public universities in Akwa Ibom State. A sample size of 464 academics was drawn from the population using hat and draw method. "Motivation and Organisational Citizenship Behaviour Questionnaire” (MOCBQ) used for data collection was validated by three validates from University of Uyo. Using Cronbach's alpha statistical tool, the test of internal consistency of the instrument yielded the coefficients of .83 for Motivation and .97 for Organisational Citizenship Behaviour. Data were analysed using simple linear regression statistics. The finding is that motivation significantly predicts organisational citizenship behaviour - altruism, sportsmanship and civic virtue - of academics of universities in Akwa Ibom State, Nigeria. Based on the findings, it is concluded that motivation could be used to explain the variation in organisational citizenship behaviour of academics in universities. It is, therefore, recommended that university authorities should explore various motivation strategies and create supportive environment for achievement, personal growth, responsibility and cross training of academics to enhance their exhibition of organisational citizenship behaviour.
\end{abstract}

Keywords: Motivation, Organisation, Citizenship, Behaviour, Academics, Universities

\section{INTRODUCTION}

University education is a critical component of human development worldwide. It provides not only the high-level skills necessary for every labour market, but also the training essentials for teachers, doctors, nurses, civil servants, engineers, humanists, entrepreneurs, scientist, social scientist, and a myriad of other personnel. It is this trained individuals who develop the capacity and analytical skills that drive local economies, support civil service, teach children, lead effective governments, and make important decisions which affect the entire society.

However, the universities need academics to accomplish their goals effectively. Hornby (1997) defines an academic as a person who teaches and/or does research at a university or college. Academics are the building blocks of universities. They influence teaching-learning outcome either positively or negatively. This due to the fact that they determine the quality of instructional delivery and also influence quality education when it comes to implementation of the curriculum and educational policies. Undoubtedly, the academics polish and impart knowledge to students, who are invariably the as pillars of a nation. Therefore, the importance of academics in any country or university system cannot be over-stressed.. Investing in the welfare of academics cannot also be ignored because human resources capital development is considered as the most powerful resource for a country's growth. It is, therefore, necessary to have highly motivated bunch of academics in the universities where their organisational citizenship behaviour is extremely demanded.

The importance of motivation to positive staff behaviour in any organisation cannot be overemphasized. The word "motivation" was derived from the Latin word "movere", which means "to move". So, motivation implies to move, push or persuade towards satisfying need which is a basic psychological process (Shahzad, Sidaiqui, \& Zakaria, 2014). Motivation is the act of providing motive that causes someone to act. Ryan and Edward (2012) agree that a motivated person is the one that is moved to do a particular act. Motivation is psychological process that commences from, or is aroused by the existence of some unsatisfied needs in a person. This need if left un-attended for a long time 
creates tension and dissatisfaction that may ultimately lead to dwindling performance on the part of the academics in particular and the university as a whole.

Therefore, the key to understanding the process of motivation lies in the meaning of, and relationship among needs, drives and incentives (Minner, Ebrahimi, \& Watchel, 1995). Maslow (1943) stated that employees have five levels of needs and that human needs were in form of a hierarchy ascending order. These Maslow notes, commences from physiological needs (the lowest). Others are, to safety needs, social needs, esteem needs and the highest being the need for self-actualization. Hence, a good pay and interesting work place, are keys to motivation for higher academics.

A functional organization needs three types of employee behaviour. (1) A behaviour of entering and remaining in the organization, (2) they must reliably carrying out specific role or job requirements; and (3) Innovative and spontaneous activity behaviour that goes beyond role perceptions (Somech, \& Ron, (2007).The third behaviour, mentioned here indicates organizational citizenship behaviour that is, behaviour that attempts to benefit the organization and that goes beyond existing role expectation (Organ, Podsakoff \&Mackensie, 2006).

Organizational citizenship behaviour can be defined as a discretionary work-related behaviour exhibited by an individual which may not necessarily be part of terms of service an employee is expected to render in an organization, but which promotes the overall status or good image of the organization (Zhong, Lam \& Chen, 2009). Discretionary work related behaviour as used in this context mean that the behaviour is neither contained in the employees job description, nor is it an enforceable requirement of the role rather, the behaviour is a matter of personal choice or volition, such that failure to perform them may not attract punishment (Padsakoff, Blume, Wkiting \& Podsakoff, 2009).

A review of related literature on this concept reveals that there is still a lack of consensus about the dimensions of this construct as over thirty potentially different dimensions of organisational citizenship behaviour reveals a great deal of conceptual overlap between the construct. For the purpose of this study, a distinction has been made between five popular dimensions of organisational citizenship behaviour that has been identified in the management literature. Podsakoff, Mckenzie, Piane and Bachranch (2010) identified seven common dimensions of organizational citizenship behaviour: altruism, sportsmanship, organizational loyalty, organizational compliance, individual initiative, civic virtue and personal development. Three of these, are the focus in the context of this study. They are Altruism (unselfishness which culminates into helping a colleague with work related task or problem); Civic virtue (This involves responsibly participating and involving in or concerned about the welfare or success of the organisation); and Sportsmanship (This involves behaviours indicating the willingness of the employee to tolerate less than ideal situations without complaining).

University academics put in time and efforts to achieve personal, economic, and non-economic satisfaction. Hence, the university should be able to create sufficient values that could compensate for the burdens imposed upon resources contributed. The question here is what strategies can be used to motivate academics? Some of the contemporary strategies are to use the payment of salaries, wages and provision of attractive conditions of service which relate to the importance which the university attaches to each job. Others are money rewards, staff training, information availability and communication, job security, physical surrounding and safety. These go a long way to ensuring equity, fairness; setting challenging, but achievable goals; specifying clear organizational structures and policies, providing performance-based rewards and incentives, among other thing When these provisions are put in place, the universities can engender job commitment and positive work related behaviours as well as facilitate motivation of academics.

Despite the fact that organizational citizenship behaviour is one of the expected behaviour that should be exhibited by academics for effective functioning of the university, it has been observed that not all academics exhibit this behaviour. Farh, Early and Lin (1997) explored whether organizational citizenship behaviour has ethical meaning in cultures in which expectations from employees differ drastically. They found that altruism, civic virtue and consciousness are relatively universal in nature. Jacqueline, Shapiro, Kessler and Purcett (2004) observed that individuals engage in organizational citizenship behaviour as a form of reciprocity based on organisational treatment. Dhitiporn and Brooklyn (2004) observed that if employees are motivated they tend to engage in pro-social behaviours. Watz and Shaffer (2005) assert that altruism may be a routine; yet, some academics count 
it as beyond the scope of job requisites. Furmann (2007) concluded in his research that high workload, large number of students in classes and burden of non-teaching activities are the prevalent problems when trying to create a good job design for academics adding that these reduce their tendency to engage in organizational citizenship behaviour. Scholars have generally observed that lack of information and feedbacks on organisations' actions and decisions lead to frustration of academics. They maintained that such factors and this disturbances impact on their performance and organizational citizenship behaviour.

In examining the consequences of motivation on organisational citizenship behaviour, researchers like Amabile, Barsade, Mueller and Staw (2005), Shaffer (2005), Algae, Ballinger, Tangirala and Oakley (2006),Salami (2010), Eatough, Chang, Miloslavic and Johnson (2012), Obiora and Okpu (2015), Hipla, Odebuji and Alabi (2014) found that there exist relationship between motivation and organizational citizenship behavior. They however, did not explain the extent to which motivation predicts the variation in organizational citizenship behaviour .Hence, the need for this study which aimed at investigating the extent to which motivation predicts organizational citizenship behaviour of academics in universities in Akwa Ibom State, Nigeria.

\subsection{Statement of the Problem}

The university plays an important role in the economy of any nation. Universities generally seek for high performance, innovations and flexibility to boost the economy of the entire world. They achieve these goals by training individuals who develop the capacity and analytical skills that drive all sectors of the world economy. However, the success of universities fundamentally depends on academics who are motivated to be committed to university goals and values. Regrettably, not all academics exhibit organizational citizenship behaviour in the university system. Perhaps such academics may perceive the university reward system as being unfair and not contingent upon performance.

May be, the academics are frustrated by lack of feedback on university decisions affecting them. Also, the academics may be inhibited by individual differences such as abilities, experiences, training and knowledge; or heavy workload, inconsistent policy implementation and cultural context which may affect the form of organizational citizenship behaviour. In examining the consequences of motivation on organisational citizenship behaviour, several studies variously found relationship between motivation and organizational citizenship behaviour without explaining the extent to which motivation predicts the variation in organizational citizenship behavior. This has created a lacuna, hence, the need for this study which aimed at investigating the extent to which motivation predicts organizational citizenship behaviour of academics in universities in Akwa Ibom State, Nigeria.

\subsection{Purpose of the Study}

This study examines the extent to which motivation predicts organizational citizenship behaviour of academics in universities in Akwa Ibom State, Nigeria. Specifically, the study examines the extent to which motivation predicts altruism, sportsmanship, and civic virtue of academics in universities in Akwa Ibom State, Nigeria.

\subsection{Research Questions}

The following research questions were raised to guide the study.

1. To what extent does motivation predict altruism of academics in universities in Akwa Ibom State, Nigeria?

2. To what extent does motivation predict sportsmanship of academics in universities in Akwa Ibom State, Nigeria?

3. To what extent does motivation predict civic virtue of academics in universities in Akwa Ibom State, Nigeria?

\subsection{Null Hypotheses}

Three null hypotheses were formulated to guide the study.

1. Motivation does not significantly predict altruism of academics in universities in Akwa Ibom State, Nigeria. 
2. Motivation does not significantly predict sportsmanship of academics in universities in Akwa Ibom State, Nigeria.

3. Motivation does not significantly predict civic virtue of academics in universities in Akwa Ibom State, Nigeria.

\section{RESEARCH METHOD}

The ex-post facto design was adopted for the study. This design is suitable since the study was undertaken after the events have taken place and the data already in existence. Also, the independent variable; motivation; and the dependent variable, organisational citizenship behaviour of academics were not manipulated by the researchers. The population of the study comprised all the 1856 academics in public universities in Akwa Ibom State: University of Uyo, and Akwa Ibom State University. The University of Uyo, Uyo and Akwa Ibom State University, IkotAkpaden had 1184 and 672 academic staff respectively. Source: Payroll unit of the universities (2016/2017) academic session.

A sample size of 464 academics representing $25 \%$ of population of academics in the two universities was selected using hat and draw simple random sampling technique. Marks of "Yes' were given to 464 ballots placed in a hat containing a total of 1856 ballots representing the population of study. The shuffled ballots were drawn one after the other to arrive at the required number of respondents.

A researcher developed instrument - "Motivation and Organisational Citizenship Behaviour Questionnaire (MOCBQ)" was used for data collection. The independent variable; motivation consisted of 7 items, while the dependent variables: altruism, sportsmanship and civic virtue consisted of 5 items each respectively. Statements about the variables were measured on four point rating scale - Strongly Agreed (SA) 4 points; Agreed (A) 3 points, Disagreed (D) 2 points and Strongly Disagreed (SD) 1 point, respectively. The respondents were required to indicate by ticking $(\sqrt{ })$ the extent to which they agreed or disagreed with the statements representing motivation and organisational citizenship behaviour of academics.

The validity of instrument was determined by one expert in educational management and two experts in department of measurement and evaluation of the University of Uyo, Uyo. The comments and suggestions by these experts were used to modify items and improve the content of the instrument.A trial test was conducted for the questionnaire using 20 academics who did not take part in the main study to establish the reliability. Copies of the questionnaire were administered once on them, after which their responses were coded and analysed using Cronbach's alpha statistical tool for the test of internal consistency. This yielded the coefficients of .83 for motivation and .97 for organisational citizenship behaviour. Copies of the instrument (questionnaire) were administered on the respondents through the permission of the Heads of Departments of the sampled population. The respondents were not allowed to compare their responses with one another. out of 464, copies of the questionnaire distributed, 416 were adequately completed and retrieved.

Data on the variables were analysed using simple linear regression statistical tool. This method of data analysis was considered appropriate since the researcher sought to determine the extent to which motivation contributes to variation in the various dimensions of organisational citizenship behaviour of academics.

\section{RESUltS}

In order to answer the research questions and test the null hypotheses simple linear regression analysis was used and the results are presented in Tables 1 to 3.

Table1. Simple linear regression analysis for the extent to which motivation predict altruism of academics

\begin{tabular}{|l|l|l|l|l|l|}
\hline Source of Variation & Sum of Squares & df & Mean Square & F & R Square \\
\hline Regression & 38.578 & 1 & 38.578 & & \\
\hline & & & & $5.51^{*}$ & .013 \\
\hline Residual & 2904.233 & 415 & 6.998 & & \\
\hline Total & 2942.811 & 416 & & & \\
\hline
\end{tabular}

Predictor: (Constant), Motivation; Dependent Variable: altruism;

$*$ Significant at .05 alpha level; $d f=F_{1,415} ;$ critical $F=3.86 ; N=416$ 
Entries in Table 1 show that the calculated F-value of 5.51 is greater than the critical F-value of 3.86 at .05 with 1 and 415 degrees of freedom. The result is significant; therefore the null hypothesis that motivation does not significantly predict altruism of academics in universities in Akwa Ibom State of Nigeria is rejected in favour of the alternate one. The result means that motivation significantly predicts the criterion variable which is altruism of academics. $\mathrm{R}^{2}$, the coefficient of determination, (.013) is the squared value of the correlation coefficient. It shows that $13 \%$ variation in altruism of academics is explained by motivation.

Table2. Simple linear regression analysis for the extent to which motivation predict sportsmanship of academics

\begin{tabular}{|l|l|l|l|l|l|}
\hline Source of Variation & Sum of Squares & df & Mean Square & F & R Square \\
\hline Regression & 449.910 & 1 & 449.910 & & \\
\hline & & & & $133.30 *$ & .243 \\
\hline Residual & 1400.656 & 415 & 3.375 & & \\
\hline Total & 1850.566 & 416 & & & \\
\hline
\end{tabular}

Predictor: (Constant), Motivation; Dependent Variable: altruism;

*Significant at .05 alpha level; $d f=F_{1,415} ;$ critical $F=3.86 ; N=416$

Entries in Table 2 show that the calculated - F value of 133.30 is greater than the critical F-value of 3.86 at .05 with 1 and 415 degrees of freedom. The result is significant; therefore the null hypothesis that motivation does not significantly predict sportsmanship of academics in universities in Akwa Ibom State of Nigeria is rejected in favour of the alternate one. The result means that motivation significantly predicts the criterion variable which is sportsmanship academics. $\mathrm{R}^{2}$, the coefficient of determination, (.243) is the squared value of the correlation coefficient. It shows that $24.3 \%$ variation in sportsmanship of academics is explained by motivation.

Table3. Simple linear regression analysis for the extent to which motivation civic virtue of academics

\begin{tabular}{|l|l|l|l|l|l|}
\hline Source of Variation & Sum of Squares & df & Mean Square & F & R Square \\
\hline Regression & 468.425 & 1 & 468.425 & & \\
\hline & & & & $291.53^{*}$ & .413 \\
\hline Residual & 66.817 & 415 & 1.607 & & \\
\hline Total & 1135.242 & 416 & & & \\
\hline
\end{tabular}

Predictor: (Constant), Motivation; Dependent Variable: altruism;

$*$ Significant at .05 alpha level; $d f=F_{1,415} ;$ critical $F=3.86 ; N=416$

Entries in Table 3 show that the calculated - F value of 291.53 is greater than the critical F-value of 3.86 at .05 with 1 and 415 degrees of freedom. The result is significant; therefore the null hypothesis that motivation does not significantly predict civic virtue of academics in universities in Akwa Ibom State of Nigeria is rejected in favour of the alternate one. The result means that motivation significantly predicts to the criterion variable which is civic virtue of academics. $\mathrm{R}^{2}$, the coefficient of determination, (.413) is the squared value of the correlation coefficient. It shows that $41.3 \%$ variation in civic virtue of academics is explained by motivation.

\section{DisCuSSION}

The testing of null hypothesis one revealed that motivation significantly predicts altruism of academics in universities in Akwa Ibom State, Nigeria. The result means that employees who are motivated will engage in helping colleagues who are absent from work, or who have heavy workloads. Such employees are also mindful of how their own behaviour affects the job of others while providing help and support to new employees. The result could be attributed to the fact that the respondents are aware of the fact that those who are motivated will likely give assistance to their colleagues. Moreover, some of them may have gotten such experience in their work place where they have voluntarily assisted others to prevent or solve work-related problems.

The result agrees with the assertion of Algae, Ballinger, Tangirala and Oakley (2006) that employees that are motivated to be creative are likely to perceive the link between their actions and broader organisational outcomes and voluntarily assume the responsibility of helping others over and above 
what is specified in their job requirements. It also agrees with the opinion by Amabile, Barsade, Mueller and Staw (2005) that motivation is associated with altruism of academics in tertiary institutions. This implies that when academics are motivated, they are likely to exhibit altruism among other discretionary behaviours (Raja \& John, 2010).

The result is not at variance with the findings by Obiora and Okpu (2015), which reported that as organisations present a climate that encourages employee to take risk to improve their work process, to come up with new ideas to improve performance; their sense of belonging (citizenship) to the organisation is enhanced and they are therefore better motivated to go the extra mile for the organisation by assisting colleagues (altruism) with heavy work load.

The testing of null hypothesis two revealed that motivation significantly predicts sportsmanship of academics in universities in Akwa Ibom State, Nigeria. The result means that employees who are motivated will be willing to tolerate the inevitable inconveniencies and impositions of work without complaining. Example of such inconveniences include inadequate laboratory, library and internet facilities, inadequate classroom and office accommodations, improper medical attention and overtime allowances as well as obsolete equipment, teaching aids or and completing a project or having a dateline brought forward. The result could be attributed to the saying that only the wearer knows where the shoe pinches. The respondents may have worked under such unfavourable conditions and endured wishing that the situation should improve for their motivation.

The result agrees with the assertion in Nwachukwu (2006) that an ideal work environment that is supportive and promotes creative thinking like in the universities is necessary for employees (academics) to challenge their imaginations; claiming that a motivated academic may not complain when they are inconvenienced by others, but would rather maintain a positive attitude even when things do not go their way. They are not offended when others do not follow their suggestions, but are willing to sacrifice their personal interest for the good of the university. They do not also take the rejection of their ideas personally.

The testing of null hypothesis three revealed that motivation significantly predicts civic virtue of academics in universities in Akwa Ibom State, Nigeria. The result means that employees who are motivated will be willing to participate actively in organisation's governance; for instance, attend meetings, engage in policy debates, and express their opinion about what strategy the organisation ought to follow.

The finding is in line with the finding by Young (2010) that motivated employees' exhibit civic virtue to reciprocate the fair treatment they receive from their organisation. When academics embark on civic virtue, they tend to understand their colleagues better, and this smoothens interpersonal relationship with less work related problems. The finding agrees with Padsakoff, Mckenzie, Piane and Bachranch's (2010) who opined that civic virtue will naturally increase when employees are motivated by cordial relationship with their supervisors. The finding also agrees with the assertion of Farzin, Mohammadreza, Morad and Maryam (2012) that when academics are satisfied that methods, mechanism, guidelines and/or processes used to make decisions that influence them are just, they may be motivated to reciprocate these gestures by displaying such discretionary work related behaviours as civic virtue among others.

\section{CONCLUSION AND RECOMMENDATIONS}

Based on the findings of this study, it was concluded that the variations in altruism, sportsmanship, and civic virtue of academics in universities in Akwa Ibom State, Nigeria are explained by motivation. Therefore, the university system should create supportive environment for achievement, personal growth, responsibility and cross training of academics to enhance their motivation and exhibition of organisational citizenship behaviour. The universities should explore various motivation strategies and treat academics as individuals so as to identify and appeal to their individual need levels as well as enhance exhibition of organisational citizenship behaviour. The universities should combine the dimensions of organisational justice to enhance the exhibition of organisational citizenship behaviour by academics in the system. 


\section{REFERENCES}

[1] Alge, B. J.; Ballinger, G. A.; Tangirala, S. \& Oakley, J. J. (2006). Information privacy in organisations: Empowering creative and extra role performance. Journal of Applied Psychology, 91(1), 221.

[2] Amabile, T. M.; Barsade, S. G.; Mucller, J. S. \& Staw, B. M. (2005). Affect and creativity at work. Administrative Science Quarterly, 50(3), 367-403.

[3] Dhitiporn, C. \& Brooklyn, C. D. (2004). The effects of internal career orientation on organisational citizenship behaviour in Thailand.Career Development International, 9, 406-423.

[4] Eatough, E. M.; Chang, C.; Mcloslavic, S. A. \& Johnson, R. E. (2011). Relationship of role stressor with organisational citizenship behaviour: A meta-analysis. Journal of Applied Psychology, 96(3), 619-32.

[5] Farh, J. L.; Early, P. C. \& Lin, S. C. (1997). Impetus for action: A cultural analysis of justice and organisational citizenship behaviour in Chinese Society. Administrative Science Quarterly, 42(3), 421-444.

[6] Farzin, F.; Mohammadreza, A.; Morad, R. D. \& Manfani, N. J. (2012). Organisational citizenship behaviour: The role of organisational justice and Leader-member exchange, interdisciplinary. Journal of Contemporary Research in Business, 3(9), 893-903.

[7] Fuhrmann, T. D. (2007). Motivating employees. Advances in diary technology, 18, 93-101.

[8] Hornby, A. S. (1997). Oxford Advanced Learner's Dictionary of current "English. $7^{\text {th }}$ Edition. New Hork. Oxford University Press.

[9] Lepine, J. A.; Erez, A. \& Johnson, D. E. (2002). The nature and dimension of organisational citizenship behaviour: A critical review and meta-analysis. Journal of Applied Psychology, 87(1), 52-65.

[10] Mackenzie, S. B.; Podsakoff, P. M. \& Ahearne, M. (1998). Some possible antecedents and consequences of in-role-and extra-role salesperson performance. Journal of Marketing, 62, 8798.

[11] Minner, J. B.; Ebrahimi, B.; \& Wachtel, J. M. (1995). How deficiency in management contributes to the United States' Competitiveness problem and what can be done about it? Human Resource Management. Fall, p. 363.

[12] Nwashukwu, C. C. (2006). Management, theory and practice. Revised Edition. Nigeria African First Publishers.

[13] Obiora, J. N. \& Okpu, T. (2015). Creativity and organisational citizenship behaviour in the Nigerian hospitality industry. International Journal of Managerial Studies and Research 3, 9-20.

[14] Organ, D. W.; Podsakoff, P. M. \& Mackenzie, S. P. (2006). Organisational citizenship behaviour. Its nature, antecedents, and consequences. London: Sage Publications.

[15] Perry-Smith, J. E. \&Shalley, C. E. (2003). The social side of creativity: A static and dynamic social network perspective. Academy of Management Review, 28, 89-106.

[16] Podsakoff, N. P.; Blume, B. D.; Whiting, S. W. \&Podsakoff, D. M. (2009). Individual - and organisational level-consequences of organisational citizenship behaviours: A meta-analysis. Journal of Applied Psychology, 94(1), 122-141.

[17] Podsakoff, P. M. \& Mackenzie, S. B. (1997). The impact of organisational citizenship behaviour on organisational performance: A review and suggestions for further research. Human Performance, 10, 133-151.

[18] Podsakoff, P.; Mckenzie, S.; Paine, J. \&Bachrach, D. (2010). Effect of organisational citizenship behaviours on selected decisions in employment interviews. Journal of applied psychology. Advanced Online Publication Journal of Management, 26(3), 523-63.

[19] Raja, U. \& Johns, G. (2010). The joint effect of personality and job scope on in-role performance, citizenship behaviour and creativity. Human Relations, 63(7), 981-1005.

[20] Ryan, R. \& Edward, L. D. (2012). Intrinsic and extrinsic motivation: Classic definitions and new directions. Contemporary Educational Psychology 25.1 (2000), 54-67. http://www.idea library.com. university of Rochester. 
[21] Salami, S. O. (2010). Conflict resolution strategies and organisational citizenship behaviour: The moderating role of trait emotional intelligence. Social behaviour and personality: An International Journal, 38(1), 75-86.

[22] Shahzad, A.; Sidaiqui, M. A. \& Zakaria, M. (2014). Linking organisational justice with organisational citizenship behaviour: Collectivism as moderator. Pakistan Journal of Commerce and Social Sciences, 8(3), 900-193.

[23] Somech, A.\& Ron, I. (2007). Promoting organisational citizenship behaviour in schools: The impact of individual and organisational characteristics. Educational Administration Quarterly, 5, $1-29$.

[24] Watz, D. \& Shaffer, M. A. (2005). Equity and relationship quality influence on organisational citizenship behaviour; the mediating role of trust in the supervisor and empowerment. Personnel Review, 34(4), 406-422.

[25] Young, I. D. (2010). Is organisational justice enough to promote citizenship behaviour at work? A retest in Korea. European Journal of Scientific Research, 45(4), 637-648.

[26] Zhong, J. A.; Lam, W. \& Chen, Z. (2009). Relationship between leader-member exchange and organisational citizenship behaviour: Examining the moderating role of empowerment. Asia Pacific Journal of Management. D0110.1007/s/0490009-9163.

\section{AUTHORS' BIOGRAPHY}

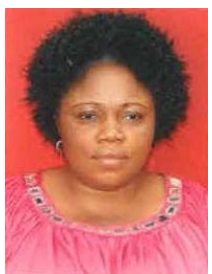

Dr Eno Etudor-Eyo, is a staff of the University of Uyo, Department of Curriculum Studies \& Educational Management. She is currently a senior lecturer.

She is a member of National Association of Educational Administration and Planning (NAEAP)

She is a member of Educational Research Network for West and Central Africa.

She is the Editor of International Journal of Innovation in Educational Management.

Dr Eno Etudor-Eyo has more than 70 publications to her credit

Ime Willie Atakpa, is a $\mathrm{PhD}$ student in the Department of Curriculum Studies \& Educational Management, University of Uyo, Nigeria. 